Jurnal ELTIKOM, Vol. 3, No. 2, Desember 2019, hal. 93-103 ISSN 2598-3245 (Print), ISSN 2598-3288 (Online)

Tersedia online di http://eltikom.poliban.ac.id DOI : http://doi.org/10.31961/eltikom.v3i2.119

\title{
SISTEM PAKAR DIAGNOSA PENYAKIT JAGUNG MANIS MENGGUNAKAN RUNUT MAJU
}

\author{
Jaka Permadi' ${ }^{1}$, Herfia Rhomadhona ${ }^{2)}$, dan Winda Aprianti ${ }^{3)}$ \\ 1,2,3) Jurusan Teknik Informatika, Politeknik Negeri Tanah Laut \\ e-mail: jakapermadi.88@gmail.com ${ }^{1)}$,herfia.rh@gmail.com ${ }^{2)}$,winda@politala.ac.id ${ }^{3)}$
}

\begin{abstract}
Cultivation of sweet corn (Zea mays saccharata) is still susceptible to disease and pest attacks. The limited knowledge possessed by farmers to handle this problem has an impact on the non-maximization of sweet corn productivity, and even tends to produce losses for farmers. The making of an expert system for diagnosis of sweet corn disease uses the forward chaining method as an aid for farmers to know the solution to be done if sweet corn plants are exposed to diseases or pest attacks. The expert system with forward chaining method that is made using 12 (twelve) diseases and 44 (forty four) symptoms. Based on the relationship of symptoms and disease, 12 (twelve) rules are obtained. Diagnosis of corn plant diseases is done by entering the symptoms of sweet corn disease and calculating the percentage of the corresponding rules. Then the highest percentage of illnesses is chosen. After obtaining a disease diagnosis, a confusion matrix test is performed. The results of test-ing for 58 test data shows the level of precision is $94.27 \%$, the level of recall is $81.67 \%$ and the level of accu-racy is $96.84 \%$.
\end{abstract}

Keywords: Testing, Corn Disease, Rule, Expert System

\begin{abstract}
ABSTRAK
Budidaya jagung manis (Zea mays saccharata) masih rentan terkena penyakit tanaman dan serangan hama. Pengetahuan terbatas yang dimiliki oleh petani untuk mengatasi permasalahan ini berdampak pada hasil produktivitas jagung manis yang tidak maksimal, bahkan cenderung menghasilkan kerugian bagi para petani. Pembuatan sistem pakar diagnosa penyakit jagung manis menggunakan runut maju diperlukan sebagai bantuan untuk para petani mengetahui solusi yang harus dilakukan jika tanaman jagung manis terkena penyakit atau serangan hama. Sistem pakar dengan metode runut maju yang dibuat menggunakan 12 (dua belas) penyakit dan 44 (empat puluh empat) gejala. Berdasarkan hubungan gejala dan penyakit diperoleh 12 (dua) belas aturan. Diagnosa penyakit tanaman jagung dilakukan dengan memasukkan gejala penyakit jagung manis dan melakukan perhitungan persentase terhadap aturan yang bersesuaian. Kemudian dipilih nilai penyakit dengan persentase terbesar. Setelah memperoleh diagnosa penyakit, dilakukan pengujian menggunakan confusion matrix. Hasil pengujian dari 58 data uji menunjukkan tingkat presisi sebesar $94.27 \%$, tingkat recall sebesar $81.67 \%$ dan tingkat akurasi sebesar $96.84 \%$.
\end{abstract}

Kata Kunci: Pengujian, Penyakit Jagung, Aturan, Sistem Pakar

\section{PENDAHULUAN}

$\mathrm{B}$ UDIDAYA jagung di Kalimantan Selatan, terutama Kabupaten Tanah Laut memiliki potensi besar menjadi penyuplai kebutuhan jagung nasional dikarenakan lahan pertanian yang bagus [1]. Potensi produksi jagung di Kabupaten Tanah Laut pada Februari 2019 sebesar 14.646 ton atau $3.63 \%$ dari total produksi jagung Kalimantan Selatan [2]. Kabupaten Tanah Laut meliputi budidaya jagung untuk pakan ternak dan jagung manis (Zea mays saccharata). Pada penelitian dengan mengambil studi kasus di Desa Sukaramah Kabupaten Tanah Laut dihasilkan bahwa pendapatan bersih petani jagung manis lebih baik dibandingkan pendapatan bersih petani jagung hibrida. Penelitian ini juga mengungkapkan bahwa pembudidayaan jagung manis masih mempunyai permasalahan untuk mengatasi penyakit atau hama yang menyerang lahan pertanian [3]. Permasalahan ini harus terdeteksi sejak dini agar dapat diberikan perlakuan yang tepat dan cepat. Berdasarkan wawancara dengan petani dan pemilik lahan diperoleh informasi bahwa kesalahan perlakuan dapat membuat kerusakan yang lebih masif bahkan dapat menyebabkan gagal panen. Tenaga ahli pada bidang pertanian jagung diperlukan untuk memberikan diagnosa penyakit dan solusinya untuk mendapatkan perlakuan yang tepat. Namun, 
jumlah tenaga ahli yang terbatas serta biaya dan waktu yang diperlukan jika menghubungi tenaga ahli membuat petani memilih untuk membuat praduga sendiri dalam mendiagnosa jenis penyakit atau hama yang menyerang lahan pertanian. Selain pembuatan praduga sendiri, petani yang bekerja sebagai buruh di lahan pertanian seringkali tidak memahami perlakuan yang harus diambil jika ada penyakit atau serangan hama. Buruh tani ini menunggu petani lain yang lebih pengalaman untuk memberikan instruksi perlakuan yang harus diambil. Hal ini berakibat pada hasil produksi budidaya jagung manis yang diperoleh petani menjadi tidak maksimal dan menyebabkan kerugian pada petani jagung.

Mengacu pada permasalahan yang telah diuraikan, maka perlu dibangun suatu sistem pakar untuk mendiagnosa penyakit jagung. Sistem pakar merupakan bagian dari Artificial intelligence (AI) yang memiliki kemampuan untuk memberikan rekomendasi solusi terhadap berbagai masalah seperti seorang pakar [4]-[7]. Sistem pakar dengan metode runut maju telah banyak diterapkan pada penelitian serupa untuk diagnosa penyakit ataupun kasus lain sebagai pengganti pendapat para ahli [8]-[10]. Amin dan Pitriani menerapkan runut maju yang memudahkan pendiagnosaan penyakit insomnia pada siswa SMK PGRI Pinang Tangerang [8]. Kosasi juga menerapkan runut maju untuk mendiagnosa penyakit pada ikan komet yang menyatakan metode ini cocok dengan penggunaan fakta atau gejala yang diderita ikan komet dan kemudian menghasilkan kesimpulan penyakitnya [9]. Penerapan runut maju untuk diagnosa karakteristik anak berkebutuhan khusus juga dilakukan oleh Rhomadhona yang menghasilkan akurasi sebesar $80 \%$. Hal ini menunjukkan sistem pakar menggunakan runut maju berfungsi untuk diagnosa karakter anak berkebutuhan khusus [10].

Berdasarkan penelitian yang telah dilakukan oleh peneliti terdahulu, sistem pakar menggunakan metode runut maju dapat membantu pengguna untuk mengambil tindakan yang diperlukan untuk mengatasi permasalahan yang dihadapi. Oleh karena itu, pada penelitian ini akan dibuat sistem pakar diagnosa penyakit jagung manis mengguanakan runut maju. Sistem pakar ini dibuat dengan menyediakan pilihan berupa gejala dari penyakit jagung secara kesuluruhan. Sistem kemudian memberikan kesimpulan berdasarkan gejala yang dipilih dan ditentukan hasilnya dengan persentase terbesar dari kemungkinan diagnosa penyakit.

\section{METODE PENELITIAN}

Alur metode penelitian sistem pakar diagnosis penyakit jagung manis dapat dilihat pada Gambar 1.

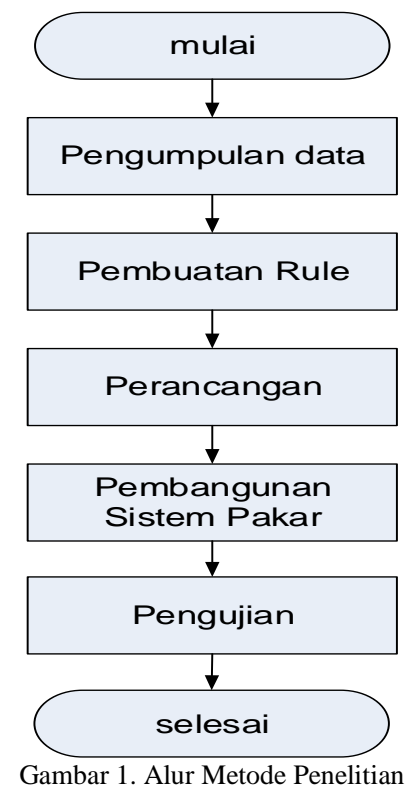

Adapun penjelasan Gambar 1 diberikan sebagai berikut.

a. Pengumpulan data gejala dan penyakit. Data pada penelitian ini merupakan data sekunder yang meliputi 6 (enam) jenis hama dan 6 (enam) jenis penyakit jagung manis, serta 44 (empat puluh empat) gejala dari hama dan penyakit yang menyerang tanaman jagung [11]. Data penyakit jagung dan gejala kemudian diwakili oleh kode sebagai identitas dari setiap penyakit dan gejala. Data 
penyakit jagung disajikan pada Tabel I dan data gejala pada Tabel II.

TABEL I

PENYAKIT JAGUNG

\begin{tabular}{cl}
\hline \hline Kode Penyakit & \multicolumn{1}{c}{ Nama Penyakit } \\
\hline P01 & Hama Uret \\
P02 & Ulat Tanah \\
P03 & Lalat Bibit \\
P04 & Ulat Grayak \\
P05 & Penggerek Batang \\
P06 & Penggerek Tongkol \\
P07 & Bulai \\
P08 & Hawar Daun \\
P09 & Karat Daun \\
P10 & Penyakit Gosong \\
P11 & Penyakit Busuk Batang \\
P12 & Virus Mosaik Kerdil Jagung \\
\hline \hline
\end{tabular}

TABEL 2.

GEJALA PENYAKIT JAGUNG

\begin{tabular}{|c|c|}
\hline Kode Gejala & Nama Gejala \\
\hline G01 & Tanaman layu \\
\hline G02 & Tanaman mati \\
\hline G03 & Ditemukan ulat putih besar(alimbatar) di dalam tanah di bawah tanaman \\
\hline G04 & Tanaman roboh \\
\hline G05 & Pada bagian batang yang patah terdapat bekas gigitan ulat \\
\hline G06 & Daun menjadi kekuningan \\
\hline G07 & Pada daun atau pucuk daun terdapat bekas gigitan \\
\hline G08 & Pertumbuhan terhambat \\
\hline G09 & Daun rusak menjadi transparan sehingga terlihat tulang daunnya saja \\
\hline G10 & Terdapat lubang kecil pada daun \\
\hline G11 & Terdapat lubang gorokan pada batang \\
\hline G12 & Terdapat lubang gorokan pada bunga jantan \\
\hline G13 & Terdapat lubang gorokan pada pangkal tongkol \\
\hline G14 & Batang dan tassel (rumbai jagung) mudah patah \\
\hline G15 & Tumpukan tassel (rumbai jagung) rusak \\
\hline G16 & Bunga jantan tidak terbentuk \\
\hline G17 & Terdapat pupa atau ulat di dalam tongkol jagung \\
\hline G18 & Terdapat garis putih-kuning sejajar tulang daun \\
\hline G19 & Permukaan daun banyak terbentuk spora seperti tepung putih \\
\hline G20 & Menyerang daun muda \\
\hline $\mathrm{G} 21$ & Daun menjadi sempit dan kaku \\
\hline $\mathrm{G} 22$ & Terbentuk anakan lebih \\
\hline G23 & Tongkol abnormal \\
\hline $\mathrm{G} 24$ & Tongkol tidak terbentuk \\
\hline $\mathrm{G} 25$ & Daun menggulung dan terpuntir \\
\hline G26 & Bunga jantan mengalami malformasi \\
\hline $\mathrm{G} 27$ & Daun sobek \\
\hline G28 & Terdapat bercak coklat kelabu seperti jerami pada permukaan daun \\
\hline G29 & Sisi bercak terletak sejajar dengan tulang daun utama \\
\hline G30 & Daun mengering \\
\hline G31 & Terdapat bintik kecil pada permukaan daun \\
\hline G32 & Bintik berwarna coklat kemerahan tersebar di permukaan daun \\
\hline G33 & Bintik berwarna hitam kecoklatan \\
\hline G34 & Pembengkakan atau gall pada tongkol $15 \mathrm{~cm}$ \\
\hline G35 & Gall berubah menjadi warna gelap \\
\hline G36 & Tanaman tiba-tiba rebah \\
\hline G37 & Pangkal batang lunak \\
\hline G38 & Batang berlendir berwarna coklat hingga berwarna coklat tua \\
\hline G39 & Batang berbau busuk \\
\hline G40 & Batang terpelintir \\
\hline G41 & Adanya warna-warna hijau muda dan tua \\
\hline G42 & Warna hijau muda memanjang sejajar dengan tulang daun \\
\hline G43 & Ukuran tongkol berkurang \\
\hline G44 & Jumlah biji berkurang \\
\hline
\end{tabular}

b. Pembuatan aturan menggunakan metode runut maju berdasarkan kajian pada [8]-[10] dan [12]-[15]. Langkah pertama pembuatan aturan untuk diagnosa penyakit jagung manis dilakukan dengan pembuatan basis pengetahuan berdasarkan pengetahuan mengenai penyakit jagung yang dimasukkan dalam Tabel Aturan (Tabel III). Kemudian Tabel Aturan diterjemahkan ke dalam pohon keputusan (Gambar 2). 


\begin{tabular}{cl}
\hline & \multicolumn{1}{c}{$\begin{array}{c}\text { TABEL III } \\
\text { TABEL ATURAN }\end{array}$} \\
\hline \hline Kode Aturan & \multicolumn{1}{c}{ Relasi Gejala Penyakit } \\
\hline R01 & Jika (G01 dan G02 dan G03 dan G04) maka P01 \\
R02 & Jika (G04 dan G05) maka P02 \\
R03 & Jika (G06 dan G07 dan (G01 atau G02 atau G08)) maka P03 \\
R04 & Jika G09 maka P04 \\
R05 & Jika (G10 dan (G11 atau G12 atau G13) dan G14 dan G15) maka P05 \\
R06 & Jika (G16 dan G17) maka P06 \\
R07 & Jika (G06 dan G08 dan G18 dan G19 dan G20 dan G21 dan G22 dan (G23 atau G24) \\
R08 & dan G25 dan G26 dan G27) maka P07 \\
R09 & Jika (G28 dan G29 dan G30) maka P08 \\
R10 & Jika (G34 dan G32 dan G33) maka P09 \\
R11 & Jika (G36 dan G37 dan G38 dan G39 dan G40) maka P11 \\
R12 & Jika (G08 dan G20 dan G41 dan G42 dan G43 dan G44) maka P12 \\
\hline \hline
\end{tabular}

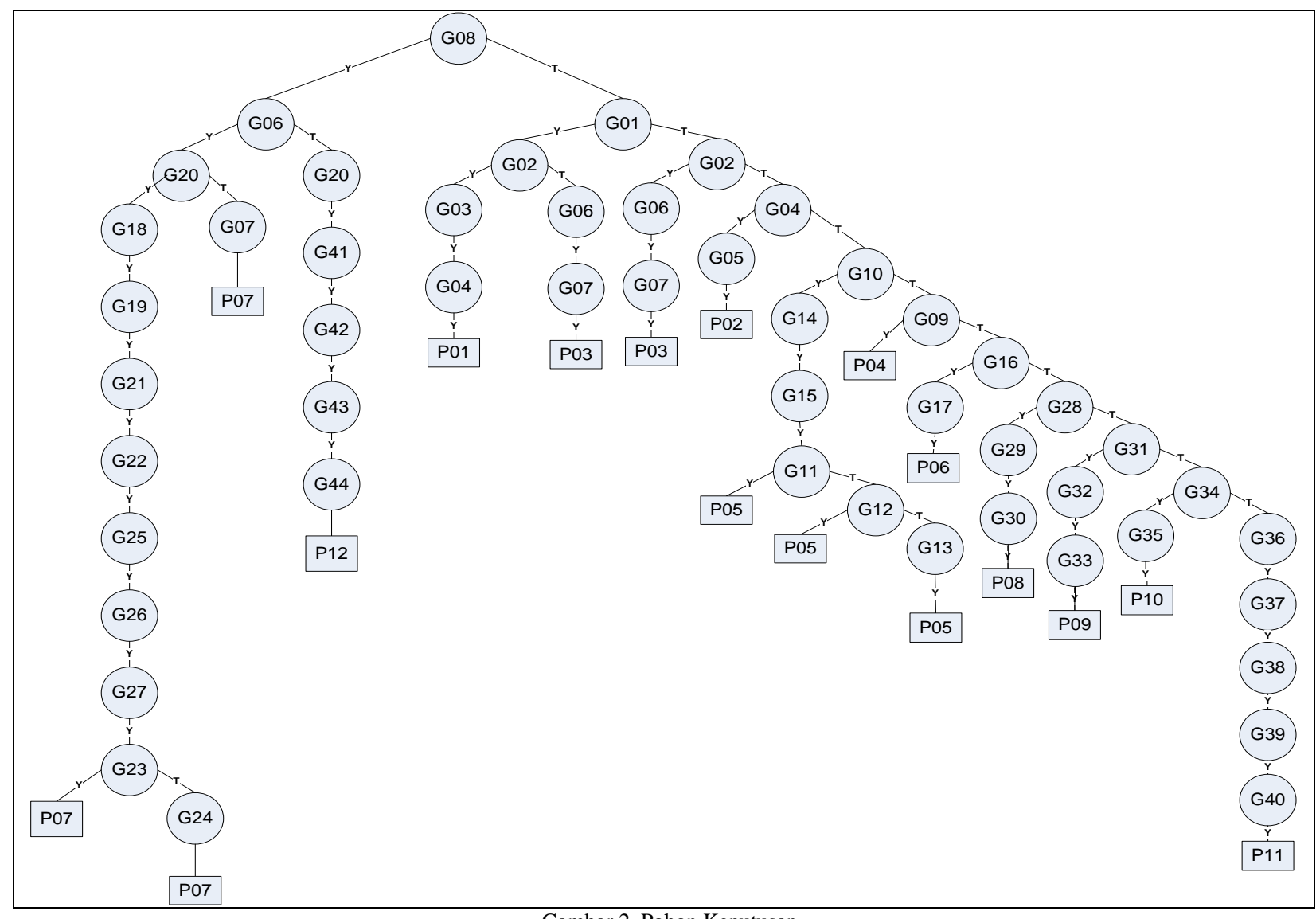

Gambar 2. Pohon Keputusan

c. penerapan aturan yang diperoleh dari Tahap b, dan perhitungan persentase penyakit. Perhitungan persentase setiap penyakit menggunakan Persamaan 1.

$$
\text { persentase penyakit }=\frac{\text { jumlah gejala yang dimasukkan }}{\text { total gejala yang ada di dalam penyakit }} \times 100 \%
$$

d. Pengujian merupakan tahapan dalam mengukur performansi dari sistem pakar, dengan menghitung akurasi, presisi dan recall berdasarkan matriks konfusion dari data uji yang telah disiapkan. Pada matriks konfusion terdapat 4 nilai yang diukur yaitu True Positive (TP), True Negative (TN), False Positive (FP) dan False Negative (FN). Pada pengujian dari suatu kelas $k$, TP adalah banyaknya data kelas $k$ yang terdeteksi benar, FP adalah banyaknya data bukan kelas $k$ yang terdeteksi sebagai kelas $k$, FN adalah banyaknya data kelas $k$ yang terdeteksi sebagai kelas bukan $k$, dan TN adalah banyaknya data kelas bukan $k$ yang terdeteksi benar. Persamaan untuk menghitung presisi, recall 
dan akurasi diperlihatkan pada Persamaan 2, 3 dan 4.

$$
\begin{aligned}
& \text { presisi }=\frac{\mathrm{TP}}{\mathrm{FP}+\mathrm{TP}} \times 100 \% \\
& \text { recall }=\frac{\mathrm{TP}}{\mathrm{FN}+\mathrm{TP}} \times 100 \% \\
& \text { akurasi }=\frac{\mathrm{TP}+\mathrm{TN}}{\mathrm{TP}+\mathrm{TN}+\mathrm{FP}+\mathrm{FN}} \times 100 \%
\end{aligned}
$$

\section{HASIL DAN PEMBAHASAN}

\section{A. Penerapan Runut Maju}

Jika gejala yang terjadi pada tanaman jagung manis adalah G11, G40, G06, G25, G27, dan G41. Langkah pertama adalah mencari gejala-gejala yang cocok pada Gambar 2 dan Tabel 3. Setelah menggunakan informasi dari Gambar 1 dan Tabel 3 diketahui bahwa gejala-gejala tersebut berada pada penyakit: P05, P11, P03, P07, dan P12. Kemudian menggunakan Persamaan (1) dihitung persentase dari setiap penyakit yang disajikan sebagai berikut.

1) Perhitungan untuk penyakit $\mathrm{P} 03$

Gejala yang dimasukkan ada 1, yakni G06

Total gejala yang ada di dalam P03 ada 3 (tiga)

$$
\text { persentase } \mathrm{P} 03=\frac{1}{3} \times 100 \%=33.33 \%
$$

2) Perhitungan untuk penyakit $\mathrm{P} 05$

Gejala yang dimasukkan ada 1, yakni G11

Total gejala yang ada di dalam P05 ada 4 (empat)

$$
\text { persentase P05 }=\frac{1}{4} \times 100 \%=25 \%
$$

3) Perhitungan untuk penyakit $\mathrm{P} 07$

Gejala yang dimasukkan ada 3, yakni G06, G25, dan G27

Total gejala yang ada di dalam P07 ada 11 (sebelas)

$$
\text { persentase } \mathrm{P} 07=\frac{3}{11} \times 100 \%=27.27 \%
$$

4) Perhitungan untuk penyakit P11

Gejala yang dimasukkan ada 1, yakni G40

Total gejala yang ada di dalam P11 ada 4 (empat)

$$
\text { persentase P11 }=\frac{1}{4} \times 100 \%=25 \%
$$

5) Perhitungan untuk penyakit $\mathrm{P} 12$

Gejala yang dimasukkan ada 1, yakni G41

Total gejala yang ada di dalam P12 ada 6 (enam)

$$
\text { persentase } \mathrm{P} 12=\frac{1}{6} \times 100 \%=16.67 \%
$$

Berdasarkan perhitungan menggunakan Persamaan (1) untuk kelima penyakit, diperoleh bahwa persentase penyakit paling besar adalah persentase untuk penyakit P03, yakni $33.33 \%$. Oleh karena itu, untuk gejala G1 1, G40, G06, G25, G27, dan G41 menggunakan runut maju disimpulkan bahwa tanaman jagung manis mengalami penyakit P03, yakni lalat bibit.

\section{B. Pengujian}

Pengujian dilakukan dengan menggunakan 58 data uji dari 12 penyakit jagung yang diperoleh dari berbagai sumber yang telah diverifikasi oleh pakar. Setiap penyakit terdiri atas 5 data uji, kecuali 
penyakit gosong yang hanya terdiri atas 3 data uji. Setiap dataset kemudian diuji menggunakan sistem pakar dengan hasil sebagai berikut.

1) Pengujian pada penyakit hama uret

Terdapat 5 data uji untuk penyakit hama uret. Output dari sistem pakar untuk kelima data uji dari penyakit hama uret disajikan pada Tabel IV.

TABEL IV

OUTPUT Sistem PAKAR PADA DATA UjI PENYAKIT HAMA URET

\begin{tabular}{clr}
\hline \hline Kode & \multicolumn{1}{c}{ Gejala } & Output Sistem Pakar \\
\hline 01 & $\begin{array}{l}\text { Daun menguning, Tanaman mati, Ditemukan ulat putih besar(alimbatar) di dalam tanah di } \\
\text { bawah tanaman }\end{array}$ & Lalat Bibit \\
02 & Tanaman layu, Tanaman mati & Hama Uret \\
03 & Tanaman mati, Ditemukan ulat putih besar(alimbatar) di dalam tanah di bawah tanaman & Hama Uret \\
04 & Tanaman layu, Tanaman roboh, Tanaman mati & Hama Uret \\
05 & Tanaman menguning, Ditemukan ulat putih besar(alimbatar) di dalam tanah di bawah & Hama Uret \\
& tanaman & \\
\hline \hline
\end{tabular}

Berdasarkan Tabel IV dapat dilihat bahwa dari 5 data uji penyakit hama uret, terdapat satu data yang terdeteksi sebagai penyakit lalat bibit, yaitu data uji dengan kode 01 . Persentase penyakit hama uret untuk data tersebut adalah sebesar 50\%, sedangkan persentase penyakit lalat bibit sebesar $67 \%$. Hal tersebut dikarenakan pada data 01 terdapat 2 gejala dari total 4 gejala pada penyakit hama uret dan 2 gejala dari total 3 gejala pada penyakit lalat bibit. Kondisi inilah yang menyebabkan persentase lalat bibit lebih besar daripada hama uret.

2) Pengujian pada penyakit ulat tanah

Terdapat 5 data uji untuk penyakit ulat tanah. Output dari sistem pakar untuk kelima data uji dari penyakit ulat tanah disajikan pada Tabel V.

TABEL V

OUTPUT SisTeM PAKAR PADA DATA UJI PENYAKIT Ulat TANAH

\begin{tabular}{clc}
\hline \hline Kode & & Gejala \\
\hline 06 & Pada bagian batang yang patah terdapat bekas gigitan ulat & Output Sistem Pakar \\
07 & Pada bagian batang yang patah terdapat bekas gigitan ulat, Tanaman mati & Ulat Tanah \\
08 & Tanaman roboh, Tanaman mati & Ulat Tanah \\
09 & Tanaman roboh & Ulat Tanah \\
10 & Pertumbuhan terhambat & Ulat Tanah \\
\hline \hline
\end{tabular}

Berdasarkan Tabel $\mathrm{V}$ dapat dilihat bahwa dari 5 data uji penyakit ulat tanah, terdapat satu data yang terdeteksi sebagai penyakit lalat bibit.

3) Pengujian pada penyakit lalat bibit

Terdapat 5 data uji untuk penyakit lalat bibit. Output dari sistem pakar untuk kelima data uji dari penyakit lalat bibit disajikan pada Tabel VI.

TABEL 6

OUTPUT SISTEM PAKAR PADA DATA UJI PENYAKIT LALAT BIBIT

\begin{tabular}{clc}
\hline \hline Kode & \multicolumn{1}{c}{ Gejala } & Output Sistem Pakar \\
\hline 11 & Pada daun atau pucuk daun terdapat bekas gigitan, Tanaman mati, Tanaman layu & Lalat Bibit \\
12 & Tanaman layu, Daun menjadi kekuningan & Lalat Bibit \\
13 & Daun menggulung dan terpuntir, Daun menjadi kekuningan, Tanaman layu, Tanaman mati & Lalat Bibit \\
14 & Terdpapat lubang gorokan pada batang, Daun menjadi kekuningan, Tanaman mati & Lalat Bibit \\
15 & Pertumbuhan terhambat, Daun menjadi kekuningan, Tanaman mati & Lalat Bibit \\
\hline \hline
\end{tabular}

Berdasarkan Tabel VI dapat dilihat bahwa seluruh data uji penyakit lalat bibit terdeteksi dengan benar.

4) Pengujian pada penyakit ulat grayak

Terdapat 5 data uji untuk penyakit ulat grayak. Output dari sistem pakar untuk kelima data uji dari penyakit ulat grayak disajikan pada Tabel VII. 
TABEL VII

OutPut Sistem Pakar Pada Data Uji Penyakit Ulat Grayak

\begin{tabular}{|c|c|c|}
\hline Kode & Gejala & Output Sistem Pakar \\
\hline 16 & Daun rusak menjadi transparan sehingga terlihat tulang daunnya saja & Ulat Grayak \\
\hline 17 & Tanaman mati & Lalat Bibit \\
\hline 18 & $\begin{array}{l}\text { Daun rusak menjadi transparan sehingga terlihat tulang daunnya saja, Pada daun atau pucuk } \\
\text { daun terdapat bekas gigitan }\end{array}$ & Ulat Grayak \\
\hline 19 & $\begin{array}{l}\text { Daun rusak menjadi transparan sehingga terlihat tulang daunnya saja, Tanaman layu, } \\
\text { Tanaman mati }\end{array}$ & Ulat Grayak \\
\hline 20 & Daun rusak menjadi transparan sehingga terlihat tulang daunnya saja, Tanaman mati & Ulat Grayak \\
\hline
\end{tabular}

Berdasarkan Tabel VII dapat dilihat bahwa dari 5 data uji penyakit ulat grayak, terdapat satu data yang terdeteksi sebagai penyakit lalat bibit, yaitu data dengan kode 17. Gejala tanaman mati bukan termasuk gejala pada penyakit ulat grayak, sehingga sistem pakar tidak menyatakan data 17 ini sebagai penyakit ulat grayak.

5) Pengujian pada penyakit penggerek batang

Terdapat 5 data uji untuk penyakit penggerek batang. Output dari sistem pakar untuk kelima data uji dari penyakit penggerek batang disajikan pada Tabel VIII.

TABEL VIII

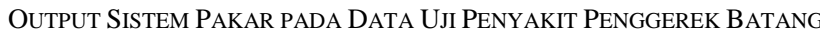

\begin{tabular}{clc}
\hline \hline Kode & \multicolumn{1}{c}{ Gejala } & Output Sistem Pakar \\
\hline 21 & $\begin{array}{l}\text { Terdapat lubang kecil pada daun, Terdapat lubang gorokan pada batang, bunga jantan atau } \\
\text { tongkol, Batang dan tassel (rumbai jagung) mudah patah, Tumpukan tassel (rumbai jagung) } \\
\text { rusak } \\
\text { Terdapat lubang kecil pada daun, Terdapat lubang gorokan pada batang }\end{array}$ & Penggerek Batang \\
22 & $\begin{array}{l}\text { Terdapat lubang kecil pada daun, Terdapat lubang gorokan pada batang, bunga jantan atau } \\
\text { tongkol, Batang dan tassel (rumbai jagung) mudah patah }\end{array}$ & Penggerek Batang \\
23 & $\begin{array}{l}\text { Terdapat lubang gorokan pada batang } \\
\text { Pada bagian batang yang patah terdapat bekas gigitan ulat, Pada daun atau pucuk daun terdapat } \\
\text { bekas gigitan, tanaman mati }\end{array}$ & Penggerek Batang \\
25 & & Lalat Bibit \\
\hline \hline
\end{tabular}

Berdasarkan Tabel VIII dapat dilihat bahwa dari 5 data uji penyakit penggerek batang, terdapat satu data yang terdeteksi sebagai penyakit lalat bibit, yaitu pada data uji dengan kode 25. Gejala-gejala pada data tersebut bukan merupakan gejala pada penyakit penggerek batang yang tersimpan di dalam basis data, sehingga sistem pakar menyatakan bahwa data tersebut bukan merupakan penyakit penggerek batang.

6) Pengujian pada penyakit penggerek tongkol

Terdapat 5 data uji untuk penyakit penggerek tongkol. Output dari sistem pakar untuk kelima data uji dari penyakit penggerek tongkol disajikan pada Tabel IX.

TABEL IX

OUTPUT SISTEM PAKAR PADA DATA UJI PENYAKIT PENGGEREK TONGKOL

\begin{tabular}{clc}
\hline \hline Kode & \multicolumn{1}{c}{ Gejala } & Output Sistem Pakar \\
\hline 26 & Terdapat pupa atau ulat di dalam tongkol jagung & Penggerek Tongkol \\
27 & Terdapat lubang kecil pada daun, Terdapat pupa atau ulat di dalam tongkol jagung & Penggerek Tongkol \\
28 & Bunga jantan tidak terbentuk, Terdapat pupa atau ulat di dalam tongkol jagung & Penggerek Tongkol \\
29 & Bunga jantan tidak terbentuk & Penggerek Tongkol \\
30 & Pada bagian batang yang patah terdapat bekas gigitan ulat, Pada daun atau pucuk daun terdapat & Penggerek Tongkol \\
& bekas gigitan, Terdapat pupa atau ulat di dalam tongkol jagung & \\
\hline \hline
\end{tabular}

Berdasarkan Tabel IX dapat dilihat bahwa seluruh data uji penyakit penggerek tongkol terdeteksi dengan benar.

7) Pengujian pada penyakit bulai

Terdapat 5 data uji untuk penyakit bulai. Output dari sistem pakar untuk kelima data uji dari penyakit bulai disajikan pada Tabel $\mathrm{X}$. 
TABEL $X$

OUTPUT SISTEM PAKAR PADA DATA UJI PENYAKIT BULAI

\begin{tabular}{|c|c|c|}
\hline Kode & Gejala & Output Sistem Pakar \\
\hline 31 & $\begin{array}{l}\text { Terdapat garis putih-kuning sejajar tulang daun, Pertumbuhan terhambat, Daun menjadi } \\
\text { kekuningan, Tongkol tidak terbentuk }\end{array}$ & Lalat Bibit \\
\hline 32 & $\begin{array}{l}\text { Daun menjadi kekuningan, Daun menjadi sempit dan kaku, Menyerang daun muda, } \\
\text { Pertumbuhan terhambat, Tongkol abnormal, Daun menggulung dan terpuntir, Jumlah biji } \\
\text { berkurang }\end{array}$ & Lalat Bibit \\
\hline 33 & $\begin{array}{l}\text { Permukaan daun banyak terbentuk spora seperti tepung putih, Daun menjadi kekuningan, } \\
\text { Daun menjadi sempit dan kaku, Menyerang daun muda, Pertumbuhan terhambat, Tongkol } \\
\text { abnormal, Daun menggulung dan terpuntir, Terdapat garis putih-kuning sejajar tulang daun, } \\
\text { Jumlah biji berkurang }\end{array}$ & Bulai \\
\hline 34 & $\begin{array}{l}\text { Daun menjadi kekuningan, Daun menjadi sempit dan kaku, Menyerang daun muda, Tongkol } \\
\text { abnormal, Jumlah biji berkurang }\end{array}$ & Bulai \\
\hline 35 & Daun menggulung dan terpuntir & Bulai \\
\hline
\end{tabular}

Berdasarkan Tabel $\mathrm{X}$ dapat dilihat bahwa dari 5 data uji penyakit bulai, terdapat dua data yang terdeteksi sebagai penyakit lalat bibit, yaitu data pada kode 31 dan 32. Pada data uji 31 persentase penyakit bulai sebesar 27\%, sedangkan persentase lalat bibit sebesar $67 \%$. Pada data tersebut jumlah gejala yang sesuai dengan gejala penyakit bulai adalah sebanyak 3 gejala dari total 11 gejala penyakit bulai. Sedangkan jumlah gejala yang sesuai dengan gejala lalat bibit adalah sebanyak 2 gejala dari total 3 gejala lalat bibit. Walaupun jumlah gejala pada data 31 lebih banyak yang sesuai pada penyakit bulai, tapi persentase kesesuaian lebi tinggi pada lalat bibit, sehingga data 31 terdeteksi sebagai penyakit lalat bibit. Hal yang sama terjadi pada data uji dengan kode 32, dimana persentase penyakit bulai sebesar 55\% dan persentase penyakit lalat bibit sebesar $67 \%$.

8) Pengujian pada penyakit hawar daun

Terdapat 5 data uji untuk penyakit hawar daun. Output dari sistem pakar untuk kelima data uji dari penyakit hawar daun disajikan pada Tabel XI.

TABEL XI

OUTPUT SISTEM PAKAR PADA DATA UJI PENYAKIT HAWAR DAUN

\begin{tabular}{|c|c|c|}
\hline Kode & Gejala & Output Sistem Pakar \\
\hline 36 & Terdapat bercak coklat kelabu seperti jerami pada permukaan daun, Daun mengering & Hawar Daun \\
\hline 37 & Terdapat bercak coklat kelabu seperti jerami pada permukaan daun & Hawar Daun \\
\hline 38 & $\begin{array}{l}\text { Terdapat bercak coklat kelabu seperti jerami pada permukaan daun, Sisi bercak terletak } \\
\text { sejajar dengan tulang daun utama }\end{array}$ & Hawar Daun \\
\hline 39 & Terdapat bercak coklat kelabu seperti jerami pada permukaan daun, Menyerang daun muda & Hawar Daun \\
\hline 40 & $\begin{array}{l}\text { Terdapat bercak coklat kelabu seperti jerami pada permukaan daun, Daun mengering, } \\
\text { Tanaman mati }\end{array}$ & Hawar Daun \\
\hline
\end{tabular}

Berdasarkan Tabel XI dapat dilihat bahwa seluruh data uji penyakit hawar daun terdeteksi dengan benar.

9) Pengujian pada penyakit karat daun

Terdapat 5 data uji untuk penyakit karat daun. Output dari sistem pakar untuk kelima data uji dari penyakit karat daun disajikan pada Tabel XII.

TABEL XII

OUTPUT SISTEM PAKAR PADA DATA UJI PENYAKIT KARAT DAUN

\begin{tabular}{|c|c|c|}
\hline Kode & Gejala & Output Sistem Pakar \\
\hline 41 & Terdapat bintik kecil pada permukaan daun & Karat Daun \\
\hline 42 & Bintik berwarna coklat kemerahan tersebar di permukaan daun & Karat Daun \\
\hline 43 & Bintik berwarna coklat kemerahan tersebar di permukaan daun, Tanaman mati & Lalat Bibit \\
\hline 44 & Bintik berwarna coklat kemerahan tersebar di permukaan daun, Pertumbuhan terhambat & Lalat Bibit \\
\hline 45 & $\begin{array}{l}\text { Bintik berwarna coklat kemerahan tersebar di permukaan daun, Bintik berwarna hitam } \\
\text { kecoklatan, Terdapat bintik kecil pada permukaan daun }\end{array}$ & Karat Daun \\
\hline
\end{tabular}

Berdasarkan Tabel 12 dapat dilihat bahwa dari 5 data uji penyakit karat daun, terdapat dua data yang terdeteksi sebagai penyakit lalat bibit, yaitu data uji dengan kode 43 dan 44 . Pada data 43 dan 44 tersebut, persentase penyakit karat daun sebesar $33 \%$ karena terdapat satu gejala dari total tiga gejala pada karat daun. Sedangkan persentase penyakit lalat bibit pada data 43 juga sebesar 33\%. Karena 
memiliki persentase yang sama, sistem pakar dapat menetapkan penyakit berdasarkan kondisi yang ditetapkan pada aplikasi sistem pakar tersebut. Pada penelitian ini, kondisi yang ditetapkan pada aplikasi sistem pakar menyebabkan penyakit pada indeks terkecil dari tabel aturan akan lebih dipilih jika terdapat kesamaan persentase tertinggi. Oleh karena itu pada kasus kode uji 43 dan 44 sistem pakar mengeluarkan hasil penyakit lalat bibit walaupun persentase lalat bibit dan karat daun sama, karena posisi lalat bibit berada pada indeks yang lebih kecil daripada karat daun.

10) Pengujian pada penyakit gosong

Terdapat 3 data uji untuk penyakit gosong. Jumlah data uji dari penyakit ini berbeda dengan penyakit yang lain, karena banyaknya kombinasi gejala dari kasus-kasus penyakit gosong yang diperoleh peneliti hanya tiga kombinasi. Output dari sistem pakar untuk ketiga data uji dari penyakit gosong disajikan pada Tabel XIII.

TABEL XIII

OUTPUT SISTEM PAKAR PADA DATA UJI PENYAKIT GOSONG

\begin{tabular}{|c|c|c|}
\hline Kode & Gejala & Output Sistem Pakar \\
\hline 46 & Pembengkakan atau gall pada tongkol, Gall berubah menjadi warna gelap & Penyakit Gosong \\
\hline 47 & Gall berubah menjadi warna gelap & Penyakit Gosong \\
\hline 48 & Pembengkakan atau gall pada tongkol & Penyakit Gosong \\
\hline
\end{tabular}

Berdasarkan Tabel XIII dapat dilihat bahwa seluruh data uji penyakit gosong terdeteksi dengan benar.

11) Pengujian pada penyakit busuk batang

Terdapat 5 data uji untuk penyakit busuk batang. Output dari sistem pakar untuk kelima data uji dari penyakit busuk batang disajikan pada Tabel XIV.

TABEL XIV

OUTPUT Sistem PAKAR PADA DATA UJI PENYAKIT BUSUK BATANG

\begin{tabular}{clc}
\hline \hline Kode & & \multicolumn{1}{c}{ Gejala } \\
\hline 49 & $\begin{array}{l}\text { Tanaman layu, Daun mengering, Batang berlendir berwarna coklat hingga berwarna } \\
\text { coklat tua, Tanaman tiba-tiba rebah } \\
\text { Tanaman layu, Daun mengering, Batang berlendir berwarna coklat hingga berwarna } \\
\text { coklat tua, Tanaman tiba-tiba rebah, Pangkal batang lunak }\end{array}$ & Penyakit Busuk Batang \\
51 & $\begin{array}{l}\text { Batang berlendir berwarna coklat hingga berwarna coklat tua, Tanaman tiba-tiba rebah, } \\
\text { Pangkal batang lunak, Pertumbuhan terhambat } \\
\text { Tanaman layu, Daun mengering, Batang berlendir berwarna coklat hingga berwarna } \\
\text { coklat tua, Tanaman tiba-tiba rebah, Pangkal batang lunak, Batang berbau busuk } \\
\text { Batang berlendir berwarna coklat hingga berwarna coklat tua, Pangkal batang lunak }\end{array}$ & Penyakit Busuk Batang \\
53 & Penyakit Busuk Batang & Penyakit Busuk Batang \\
\hline \hline
\end{tabular}

Berdasarkan Tabel XIV dapat dilihat bahwa seluruh data uji penyakit busuk batang terdeteksi dengan benar.

12) Pengujian pada penyakit virus mosaik kerdil jagung

Terdapat 5 data uji untuk penyakit virus mosaik kerdil jagung. Output dari sistem pakar untuk kelima data uji dari penyakit virus mosaik kerdil jagung disajikan pada Tabel XV.

TABEL XV

OUTPUT SISTEM PAKAR PADA DATA UJI PENYAKIT VIRUS MOSAIK KERDIL JAGUNG

\begin{tabular}{|c|c|c|}
\hline Kode & Gejala & Output Sistem Pakar \\
\hline 54 & $\begin{array}{l}\text { Daun menjadi kekuningan, Menyerang daun muda, Bintik berwarna coklat kemerahan tersebar di } \\
\text { permukaan daun, Pertumbuhan terhambat, Ukuran tongkol berkurang, Adanya warna-warna hijau } \\
\text { muda dan tua }\end{array}$ & Lalat Bibit \\
\hline 55 & $\begin{array}{l}\text { Menyerang daun muda, Adanya warna-warna hijau muda dan tua, Daun menjadi kekuningan, } \\
\text { Bintik berwarna coklat kemerahan tersebar di permukaan daun, Pertumbuhan terhambat }\end{array}$ & Lalat Bibit \\
\hline 56 & Pertumbuhan terhambat, Adanya warna-warna hijau muda dan tua, Daun menjadi kekuningan & Lalat Bibit \\
\hline 57 & $\begin{array}{l}\text { Pertumbuhan terhambat, Adanya warna-warna hijau muda dan tua, Warna hijau muda } \\
\text { memanjang sejajar dengan tulang daun }\end{array}$ & $\begin{array}{l}\text { Virus Mosaik Kerdil } \\
\text { Jagung }\end{array}$ \\
\hline 58 & $\begin{array}{l}\text { Menyerang daun muda, Adanya warna-warna hijau muda dan tua, Warna hijau muda memanjang } \\
\text { sejajar dengan tulang daun, Pertumbuhan terhambat, Ukuran tongkol berkurang, Jumlah biji } \\
\text { berkurang }\end{array}$ & $\begin{array}{l}\text { Virus Mosaik Kerdil } \\
\text { Jagung }\end{array}$ \\
\hline
\end{tabular}


Berdasarkan Tabel 15 dapat dilihat bahwa dari 5 data uji penyakit virus mosaik kerdil jagung, terdapat tiga data yang terdeteksi sebagai penyakit lalat bibit, yaitu pada data uji dengan kode 54 , 55 dan 56. Pada data uji 54 persentase virus mosaik kerdil jagung sebesar $67 \%$ dan persentase lalat bibit juga sebesar $67 \%$. Karena posisi lalat bibit pada tabel aturan berada pada indeks yang lebih kecil, maka data 54 terdeteksi sebagai lalat bibit. Pada data uji 55 persentase virus mosaik kerdil jagung sebesar 50\%, sedangkan persentase lalat bibit sebesar $67 \%$, sehingga data 55 terdetksi sebagai lalat bibit. Pada data uji 56 persentase virus mosaik kerdil jagung sebesar 33\%, sedangkan persentase lalat bibit sebesar 67\%, sehingga data 56 terdeteksi sebagai lalat bibit.

13) Hasil pengujian

Hasil pengujian dengan menggunakan matriks konfusion disajikan pada Tabel XVI.

TABEL XVI

HASIL PENGUJIAN

\begin{tabular}{|c|c|c|c|c|c|c|c|c|}
\hline No & Penyakit & $\mathrm{TP}$ & $\mathrm{FN}$ & $\mathrm{FP}$ & $\mathrm{TN}$ & Presisi & Recall & Akurasi \\
\hline 1 & Hama Uret & 4 & 1 & 0 & 53 & $100.00 \%$ & $80.00 \%$ & $98.28 \%$ \\
\hline 2 & Ulat Tanah & 4 & 1 & 0 & 53 & $100.00 \%$ & $80.00 \%$ & $98.28 \%$ \\
\hline 3 & Lalat Bibit & 5 & 0 & 11 & 42 & $31.25 \%$ & $100.00 \%$ & $81.03 \%$ \\
\hline 4 & Ulat Grayak & 4 & 1 & 0 & 53 & $100.00 \%$ & $80.00 \%$ & $98.28 \%$ \\
\hline 5 & Penggerek Batang & 4 & 1 & 0 & 53 & $100.00 \%$ & $80.00 \%$ & $98.28 \%$ \\
\hline 6 & Penggerek Tongkol & 5 & 0 & 0 & 53 & $100.00 \%$ & $100.00 \%$ & $100.00 \%$ \\
\hline 7 & Bulai & 3 & 2 & 0 & 53 & $100.00 \%$ & $60.00 \%$ & $96.55 \%$ \\
\hline 8 & Hawar Daun & 5 & 0 & 0 & 53 & $100.00 \%$ & $100.00 \%$ & $100.00 \%$ \\
\hline 9 & Karat Daun & 3 & 2 & 0 & 53 & $100.00 \%$ & $60.00 \%$ & $96.55 \%$ \\
\hline 10 & Penyakit Gosong & 3 & 0 & 0 & 55 & $100.00 \%$ & $100.00 \%$ & $100.00 \%$ \\
\hline 11 & Penyakit Busuk Batang & 5 & 0 & 0 & 53 & $100.00 \%$ & $100.00 \%$ & $100.00 \%$ \\
\hline 12 & Virus Mosaik Kerdil Jagung & 2 & 3 & 0 & 53 & $100.00 \%$ & $40.00 \%$ & $94.83 \%$ \\
\hline \multicolumn{6}{|c|}{ Rata-Rata } & $94.27 \%$ & $81.67 \%$ & $96.84 \%$ \\
\hline
\end{tabular}

Berdasarkan hasil pengujian pada Tabel XVI dapat dilihat bahwa nilai presisi terkecil terdapat pada penyakit lalat bibit, yaitu sebesar $31,25 \%$. Keadaan ini diakibatkan karena sebelas penyakit yang bukan penyakit lalat bibit, terdeteksi sebagai penyakit lalat bibit. Sehingga nilai dari false positive (FP) dari penyakit lalat bibit sangat tinggi. Sangat rendahnya nilai presisi pada lalat bibit mengakibatkan nilai akurasi dari penyakit lalat bibit lebih rendah daripada penyakit lainnya, yaitu sebesar $81,03 \%$. Nilai recall terendah dimiliki oleh penyakit virus mosaik kerdil jagung, yaitu sebesar $40 \%$. Keadaan ini diakibatkan karena tiga data uji penyakit ini terdeteksi sebagai penyakit lalat bibit, sehingga meningkatkan nilai false negative (FN). Nilai presisi, recall dan akurasi tertinggi terdapat pada penyakit penggerek tongkol, hawar daun, penyakit gosong dan penyakit busuk batang yang mencapai $100 \%$. Keadaan ini dikarenakan semua data uji pada keempat penyakit tersebut terdeteksi dengan benar dan tidak ada data uji dari penyakit lainnya yang terdeteksi sebagai keempat penyakit tersebut. Rata-rata dari nilai presisi adalah sebesar $94.27 \%$, nilai recall sebesar 81.67\% dan nilai akurasi sebesar 96.84\%. Berdasarkan rata-rata tersebut dapat disimpulkan bahwa sistem pakar menggunakan runut maju baik digunakan untuk mendiagnosa penyakit jagung manis.

\section{KESIMPULAN}

Berdasarkan uraian yang telah dipaparkan, diperoleh bahwa sistem pakar diagnosa penyakit jagung menggunakan runut maju telah dibangun dengan melihat kesesuaian 44 (empat puluh empat) gejala untuk 12 (dua belas) penyakit, baik yang disebabkan oleh penyakit maupun serangan hama. Sistem pakar ini menghasilkan 12 (dua belas) aturan. Penggunaan metode runut maju untuk mendiagnosa penyakit dilakukan dengan memasukkan gejala penyakit dan melakukan perhitungan persentase penyakit yang bersesuaian dengan gejala penyakitnya. Hasil diagnosa penyakit merupakan penyakit dengan nilai persentase penyakit tertinggi. Setelah memperoleh hasil diagnosa, dilakukan pengujian menggunakan matriks konfusion dari 58 data uji yang menghasilkan tingkat presisi sebesar $94.27 \%$, tingkat recall sebesar $81.67 \%$ dan tingkat akurasi sebesar $96.84 \%$.

Pada penelitian ini, sistem pakar dibangun berdasarkan perbandingan jumlah kesesuaian gejala, sehingga kemungkinan ketidaksesuaian gejala dengan penyakit di tabel aturan tinggi. Oleh karena itu, untuk penelitian selanjutnya, perlu penambahan metode certainty factor (CF). 


\section{UCAPAN TERIMA KASIH}

Penulis mengucapkan terima kasih kepada Politeknik Negeri Tanah Laut atas bantuan biaya pada skema Penelitian Dosen Dana DIPA Tahun Anggaran 2019.

\section{DAFTAR PUSTAKA}

[1] M. Desrianto, "Mentan Optimis Kalimantan Menjadi Penyuplai Jagung Nasional," Kompas.com, 2019.

[2] L. Thohir, "Kalsel Fokus Tingkatkan Produksi Jagung," Antara Kalsel, $2019 . \quad[$ Online]. Available: https://kalsel.antaranews.com/berita/85802/kalsel-fokus-tingkatkan-produksi-jagung. [Accessed: 11-Jun-2019].

[3] M. A. Lazuardi, M. Rosni, and N. D. Yanti, "Analisis Perbandingan Biaya dan Pendapatan Bersih Usahatani Jagung Manis dengan Jagung Hibrida di Desa Suka Ramah Kecamatan Panyipatan Kabupaten Tanah Laut,” Front. Agribisnis, vol. 3, no. 1, pp. 119-127, 2019.

[4] Marimin, Teori dan Aplikasi Sistem Pakar dalam Teknologi Manajerial. Bandung: IPB Press, 2007.

[5] B. H. Hayadi, Sistem Pakar. Yogyakarta: Deepublish, 2018.

[6] Kusrini, Sistem Pakar Teori dan Aplikasi. Yogyakarta: Penerbit Andi, 2006

[7] R. Rosnelly, Sistem Pakar: Konsep dan Teori. Yogyakarta: Penerbit Andi, 2012.

[8] R. Amin and P. Pitriani, "Penerapan Metode Forward Chaining Untuk Diagnosa Penyakit Insomnia," Maret, vol. 14, no. 1, p. $97,2018$.

[9] S. Kosasi, "Komet Menggunakan Forward Chaining," Techsi, vol. 5, no. 2, pp. 35-52, 2014

[10] Rhomadhona, H. "Sistem Pakar Diagnosa Karakteristik Anak Berkebutuhan Khusus Menggunakan Metode Forward Chaining" Jurnal Sains dan Informatika, vol.3 no.1, pp. 18-26, 2017.

[11] M. Syukur and A. Rifianto, Jagung Manis. Jakarta Timur: Penebar Swadaya, 2013.

[12] N. Jarti and R. Trisno, "Sistem Pakar Diagnosa Penyakit Alergi pada Anak Berbasis Web dengan Metode Forward Chaining," J. Edik Inform., vol. 2, pp. 197-205, 2017

[13] W. Supartini and H. Hindarto, "Sistem Pakar Berbasis Web Dengan Metode Forward Chaining Dalam Mendiagnosa Dini Penyakit Tuberkulosis Di Jawa Timur," Kinetik, vol. 1, no. 3, p. 147, 2016.

[14] E. Ongko, "Perancangan Sistem Pakar Diagnosa Penyakit pada Mata," J. TIMES, vol. 2, no. 2, pp. 10-17, 2013.

[15] S. Azhar, H. L. Sari, and L. N. Zulita, "Sistem Pakar Penyakit Ginjal Pada Manusia," vol. 10, no. 1, pp. 16-26, 2014. 